\title{
Inter-organizational Relationships Networks in Internationalization Process of Exporting Companies
}

\author{
Fabiane Cortez Verdu ${ }^{1}$, Mauricio Reinert ${ }^{2}$
}

${ }^{1}$ Universidade Estadual de Maringá - e-mail: fabiane.verdu@uol.com.br

2 Universidade Estadual de Maringá - e-mail: m.reinert@uol.com.br

\section{KEYWORDS}

Networks,

Inter-organizational

Networks,

Social Network,

Exporting companies

Received 107.07.2015

Revised 04.04.2016

Accepted 11.05. 2016

ISSN 1980-4431

Double blind review

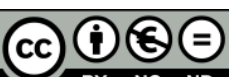

\begin{abstract}
This research aimed to characterize the interorganizational network of exporting companies in Maringá (PR). Social Network perspective is used to discuss the interorganizational relationship through concepts such as centrality, strong and weak ties, social embeddedness, embedded ties and arms-length ties. The population was 47 and the questionnaires were applied in 31 exporting companies, $66 \%$ of the population. When dealing with their relationships with organizations, the exporting companies concentrate their relationships on the value chain (buyers and suppliers). These relationships tend to be embedded and frequent, where each company plays only one role in relation to the other. Even though only four exporting companies cited their competitors as organizations with which they keep a more frequent contact, there is evidence of the existence of coopetition in these relationships. Eight exporting companies mentioned trade associations and companies formed by competitors as institutions with which they keep frequent contact, that is, these companies keep contact with competitors through institutions (evidence of the existence of coopetition). Limitations: The number of companies in the sample limits the statistical analysis. In trying to mitigate this problem, all the questionnaires were applied in loco assuring that the respondents were the correct informants. The number of variables in the ANOVA - GLM was limited to two, trying to keep the statistical power. As research suggestion, the population should be expanded. The role of institutions should be analyzed in depth, especially of the Mercosul Institute and the Banco do Brasil. The role of institution in the coopetition should be analyzed.
\end{abstract}

\section{Introduction}

The researches on social networks are not recent. Among the pioneering work on social networks, two stand out: The strength of weak ties and Getting a job, both from Mark Granovetter, an American sociologist. The works were published, respectively, in 1973 and 1974. These works (Granovetter, 1973, 1974) introduced the discussion about the role of the networks in the promotion and access to existing opportunities in the social and economic structure and the job market. In the organizational theory, the social network perspective emerged in the end of the 1970s, when authors such as Aldrich (1979) started to make use of the forms of interorganizational relationships as an analysis focus (Martes; Bulgacov; Reinert; Gonçalves; Augusto, 2006).

In Brazil, the studies on social networks have intensified in the last decade (Boehe and Toni, 2006; Bulgacov and Verdu, 2001; Maciel, 2007; Reinert, 2008a, 2008b, 2006; Rezende and Versiani, 2007). National research on networks, as well as international, concentrate on two approaches: networks as a way of governance and

Revista de Negócios, v. 20, n. 3, p. 7-15, July, 2015. 
networks as an analytical tool. In the first approach, research deals with corporate structures that take the network format. In the second, research discusses social relationships, social embeddedness, social capital and the construction of the network by using specific methodological procedures (Martes et al., 2006).

When studying interorganizational social networks through social network theory, the assumption that organizations are embedded in a network of social relationships is made, a network that influences the economic action (Smelser and Swedberg, 2005). In other words, the organizations are not independent in relation to other organizations, that is, there is interdependency between organizations that may facilitate or hamper economic action. This interdependency can be exemplified by the fact that organizations are unable to generate all the resources necessary to sustain themselves (Aldrich and Pfeffer, 1976) and enable their internationalization, so the organizations, through their relationship networks, seek to obtain the necessary resources to reach their organizational objectives.

The studies on international business are also not recent. The most commonly used model in the literature on internationalization is the School of Uppsala proposed by Johanson and Valhne (1977) (Chetty and Campbell-Hunt, 2004). However, Johanson and Valhne (2003) argue that the traditional models of internationalization, such as the original model of Uppsala and the stage model in the export process and model of innovation, among others, should be combined with new models, for not being able to explain the internationalization of certain types of companies such as born global and small businesses. The authors combined the mechanisms of the original model with the network vision focusing on the critical role of building and changing relationships in the internationalization process, which becomes the network approach to internationalization. From the need to consider new models, many lines of research on international business, partially connected, have emerged, such as new ventures or born global, high technology companies, industrial service companies and small businesses. A common feature of these many lines of research is that they emphasize the networks when they try to understand and explain the rapid internationalization of these companies (Johanson and Valhne, 2003).

The issues that permeate this research are not new, but the purpose of this research is to contribute to aspects still little explored in the literature. The literature on international activities companies emphasizes limits to internationalization, such as lack of resources (financial, human, etc.) and knowledge (especially on markets and overseas experience), which can be overcome through networking relationships (Chetty and Angdal, 2007; Chetty and CampbellHunt, 2004; Freeman, Edwards and Schroder, 2006). Regarding the internationalization, these relationships have been discussed by several authors (Boehe and Toni, 2006; Chen and Chen, 1998; Chetty and Agndal, 2007; Chetty and Campbell-Hunt, 2004; Child and Rodrigues, 2006; Loane and Bell, 2006; Lorga, 2002; Mort and Weerawardena, 2006; Rezende and Versiani, 2007; Seppo, 2007) by the network approach to internationalization (Johanson and Valhne, 2003). The perspective of social networks and the network approach to internationalization have the same assumptions, but the literature on social networks is wider with respect to different types of relationships. By using a social perspective, it is possible to better analyze how different relationships affect the internationalization, which is an economic action (Swedberg and Granovetter, 2001). The originality of this work is focused on the fact that none of these previous works used the theory of social networks to study the internationalization of companies.

The practical relevance of this research is shown as managers understand that internationalization requires resources that can be acquired through inter-organizational relationships and the internationalization process is associated with the ability of the company to maintain interorganizational relationships and to access resources through these.

This study, in turn, has as its main objective to characterize the inter-organizational network of exporting companies in Maringá (PR).

\section{Theoretical Framework}

Here this study's theoretical table is presented. The objective is not the full discussion of subjects related to the research, but to present

Revista de Negócios, v. 20, n. 3, p. 7-15, July, 2015. 
the foundations on which this work was built upon.

\subsection{Social networks}

A relationship is a connection between two agents (organizations, people, societies or even States) (Ross and Robertson, 2007). In turn, a network is a structure made of the relationships between the aforementioned agents (Scott, 2003).

When relationships happen between companies, they are called interorganizational and may be defined as the transactions, the flow and the links of resources relatively lasting, that happen between two or more organizations (Oliver, 1990). These relationships with external partners are extremely important to a $21^{\text {st }}$ century company (Ross and Robertson, 2007). The relationships have shape and content. The shape or structure represent all the links the agents maintain with other agents, that is, it is the network design that shows the quantity of connections. The content refers to the quality of the relationships, namely, the type of relationship between the two agents. The relationship content also includes the flow of resources and information, council or friendship (Powell and Smith-Doerr, 1994).

One of the ways to study shape or structure of the interorganizational social networks is to use centrality measures. The agent's centrality reveals its importance within a network; the bigger the centrality, the more important it is. Agents with bigger centrality in a network maintain more ties with other agents, than the other agents (Wasserman and Faust, 1999).

As in relation to the content, interorganizational relationships may be simple or compound. The simple one occurs when one company has only one type of relationship with another company. The compound happens when one company has simultaneously more than one type of relationship within another company. For example, DuPont is a competitor, partner, buyer and supplier of Celanese, another chemical company. A compound relationship includes all the dyadic relationships that exist between two companies, but represents only one link in a social network (Ross and Robertson, 2007).

Another representative work on the study of relationships' content is Granovetter's theory (1973) of weak and strong ties. A strong tie relationship characterizes itself by frequent interactions that supply access to available information and resources within the acting social circles themselves (Granovetter, 1983). By contrast, a weak tie relationship characterizes itself by sporadic interactions that supply access to information and resources beyond those available within the agents' social circles (Granovetter, 1983).

Still regarding the content, there is Uzzi's work (1997), in which the interorganizatinal relationships can be classified as embedded ties and arm's-length ties. Embedded ties reflect the social embeddedness concept (Granovetter, 1985), that is, the personal nature of business relationships and its effects on the economic process. Embedded ties present the following characteristics: trust, fine-grained information transfer and joint problem-solving arrangements, which in turn can generate benefits such as privileged access to resources, organizational performance improvement, etc. (Uzzi, 1997). Over-embeddedness, however, generates problems such as reduction of the flow of new information within the network, since coinciding ties with partners of the same network mean that there is little to no connection to external members that may contribute with innovative ideas (Burt, 1992).

Arm's-length (or market) ties reflect the economic nature of business and present the following characteristics: lack of reciprocity between exchange partners, no repeat interaction

Revista de Negócios, v. 20, n. 3, p. 7-15, July, 2015. 
and economic focus on the transactions. Therefore, there is no social content in the relationships between partners, business deals are one time only between said partners and the focus is the costs of the deals (Uzzi, 1997).

Uzzi (1997) highlights the importance of the two types of ties in order for the organizations to gain a competitive edge. Each type of tie offers different opportunities: embedded ties supply better access to the benefits that circulate on the network, while arm's-length ties help prevent the complete isolation of the market demand and give access to new information.

It is important to emphasize that while Granovetter's theory $(1973,1983)$ on weak and strong ties focuses on the frequency (intensity) of the interactions, Uzzi's theory (1997) on embedded and arm's-length (market) ties stresses the depth of the relationships. Furthermore, the relationships may be simple and compound (Ross and Robertson, 2007). Thus, there is the possibility of combining frequency, depth and quantity of the roles played (one or more), which results in eight types of relationship (Figure 1).

Figure 1. Relationships resulting from the combination of the attributes of the different types of ties

\begin{tabular}{|c|c|c|c|}
\hline & & $\begin{array}{c}\text { Embedded } \\
\text { Ties }\end{array}$ & $\begin{array}{l}\text { Arm's-length } \\
\text { (Market) Ties }\end{array}$ \\
\hline \multirow[t]{2}{*}{$\begin{array}{c}\text { Strong } \\
\text { Ties }\end{array}$} & Simple & $\begin{array}{c}\text { More frequency } \\
\text { and depth - } \\
\text { Type } 1 \mathrm{~A}\end{array}$ & $\begin{array}{c}\text { More } \\
\text { frequency and } \\
\text { less depth - } \\
\text { Type 2A }\end{array}$ \\
\hline & Compound & $\begin{array}{c}\text { More frequency } \\
\text { and depth - } \\
\text { Type 1B }\end{array}$ & $\begin{array}{c}\text { More } \\
\text { frequency and } \\
\text { less depth - } \\
\text { Type 2B }\end{array}$ \\
\hline \multirow[t]{2}{*}{$\begin{array}{l}\text { Weak } \\
\text { Ties }\end{array}$} & Simple & $\begin{array}{l}\text { Less frequency } \\
\text { and more depth } \\
\text { - Type 3A }\end{array}$ & $\begin{array}{c}\text { Less } \\
\text { frequency and } \\
\text { depth - Type } \\
4 \mathrm{~A}\end{array}$ \\
\hline & Compound & $\begin{array}{l}\text { Less frequency } \\
\text { and more depth } \\
- \text { Type } 3 \mathrm{~B}\end{array}$ & $\begin{array}{c}\text { Less } \\
\text { frequency and } \\
\text { depth - Type } \\
\text { 4B }\end{array}$ \\
\hline
\end{tabular}

Source: prepared by the author, based upon Granovetter (1973, 1983), Uzzi (1997) and Ross and Robertson (2007).

A type 1A relationship is characterized by frequent interactions, more social embeddedness and one role played. A type 1B is characterized by frequent interactions, more social embeddedness and more than one role played. A type $2 \mathrm{~A}$ is characterized by frequent interaction, small social embeddedness and one role played. A type $2 \mathrm{~B}$ is characterized by frequent interactions, small social embeddedness and more than one role played. A type $3 \mathrm{~A}$ is characterized by sporadic interactions, great social embeddedness and one role played. A type $3 \mathrm{~B}$ is characterized by sporadic interactions, great social embeddedness and more than one role played. A type $4 \mathrm{~A}$ is characterized by sporadic interactions, less social embeddedness and a role played. A type 4B is characterized by sporadic social interactions, less social embeddedness and more than a role played.

Relationships may occur between competitors, partners, buy from organizations and suppliers. They may be less or more frequent and deep, as well as influence the agents' economic actions.

\subsubsection{Social networks and economic action}

Economic sociology may be defined, in a simple manner, as the sociological perspective applied to economic phenomena, and, in a more elaborate manner, as the application of theoretical frameworks, variables and sociological explanatory models to the array of activities which refer to product production, distribution, exchange and consumption as well as limited service (Smelser and Swedberg, 2005, p. 3).

To the new economic sociology, the concept of social embeddedness is fundamental, which can be defined as the overlapping between social relations, ties between the network agents and economic actions (Granovetter, 1985). In other words, embeddedness means that the economic actions are embedded within the social network structure.

The study of the networks, such as the works by Burt (1992), Uzzi (1997) and Powell and Smith-Doerr (1994), have been the center of the new economic sociology (Smelser and Swedberg, 2005).

The relationships may be cooperative or competitive, which will be discussed next.

\section{relationships \\ 2.1.2 Cooperation and competition in}

The increase in the intensity of relationships has been one of the ways chosen by the companies with the objective of survival (Aldrich, 1979; Castells, 1999).The theory and the research on interorganizational relationships are being

Revista de Negócios, v. 20, n. 3, p. 7-15, July, 2015. 
discussed through two paradigms: the competitive and the cooperative, which try to explain the advantages of those companies when compared to the others. (M'Chirgui, 2005).

The competitive paradigm has excelled in the theory, research and the practice of strategic administration (Lado, Boyd and Hanlon, 1997). Understanding the sources of competitive advantage, which explain varying levels of profitability, has become the main area of research in strategic administration (Barney, 1991; Porter, 1986). The two most often used paradigms to explain the competitive advantages are the Positioning School (Porter, 1986), which argues that the competitive advantage is derived from an advantageous position in the industry, and the Resource Based View, which stipulates that the competitive advantage is a result of the mobilization and development of resources, competences and capabilities (Barney, 1991; Hamel and Prahalad, 1990, 1995, 1998; Teece, Pisano and Shuen, 1997; Wernerfelt, 1984), that allow the company to offer to consumers, superior products than its competitors (Lado et al., 1997).

The cooperative paradigm, in turn, emphasizes the development of the collaborative advantage. Within this paradigm, the business world is made up of an interdependent social network developed and encouraged through strategic collaboration in order to reach mutual benefits (Lado et al., 1997). The cooperative strategy (or cooperative game, if using game theory terminology) happens when two individuals (companies or states) are capable of discussing the situation and agree on a rational joint plan of action, an agreement that should be met (Nash, 1953).

The cooperative game presupposes a bargaining situation, in which agents have the opportunity to collaborate to the mutual benefit in more than one way (Nash, 1950; Rubinstein, 1995). Researchers know that in an environment increasingly complex and turbulent, companies can improve their performance through strategic collaboration (Lado et al., 1997). The recent interest in cooperative strategy is based in the widely accepted notion that organizations are cooperative systems by nature (Barnard, 1979) that emphasize the harmonious interdependence between subsystems (Lado et al., 1997).

Each of these perspectives, competitive and cooperative, offering only a partial view of the reality. Success in the business world of today requires that companies pursue competitive and cooperative strategies simultaneously. To improve their competitiveness, companies must adopt behaviors that reinforce the cooperation and trust and, in order to be effective collaborators, companies should compete for competences (Lado et al., 1997). Thus, cooperation may elevate the competitive position of a company (Chien and Peng, 2005; Lado et al., 1997).

To Lado et al. (1997), competition and cooperation are not the opposed sides of a continuum; they are independent variables which interaction or interdependency must be studied, to explain success in today's business world.

When the nature of the relationship between competitors is analyzed, there are four types of relationship that can be identified (see figure 2), taking into account the trade-off between cooperation and competition (Bengtsson and Kock, 1999; Lado et al., 1997).

Monopolistic or co-existential behavior characterizes itself by low competition and cooperation and does not include interaction between competitors. Cooperative behavior is characterized by high cooperation and low competitiveness between the companies that seek mutual benefits through additional resources, abilities and capabilities. The competitive behavior is characterized by high competitiveness and low cooperation, which reflect an entrepreneurial orientation to reach a superior performance position and generate a competitive advantage over the other companies. The coopetitive behavior, in turn, characterizes itself by high cooperation and competitiveness, both reflected in a combination between cooperative and competitive strategies (Lado et al., 1997).

Figure 2. Strategic behaviors

\begin{tabular}{|l|l|l|l|}
\hline \multicolumn{2}{|c|}{} & \multicolumn{2}{|c|}{ Competitive orientation } \\
\cline { 3 - 4 } \multicolumn{2}{|c|}{} & Low & High \\
\hline $\begin{array}{l}\text { Cooperative } \\
\text { Orientation }\end{array}$ & High & $\begin{array}{l}\text { Cooperative } \\
\text { behavior }\end{array}$ & $\begin{array}{l}\text { Coopetitive } \\
\text { Behavior }\end{array}$ \\
\cline { 2 - 4 } & Low & $\begin{array}{l}\text { Monopolistic or } \\
\text { co-existential } \\
\text { behavior }\end{array}$ & $\begin{array}{l}\text { Competitive } \\
\text { behavior }\end{array}$ \\
\hline
\end{tabular}

Source: Adapted from Bengtsson and Kock (1999) and from Lado et al. (1997).

The results from Uzzi's work (1999) suggest in embedded ties relationships there are simultaneously cooperation and competition, 
while in arm's-length ties competition predominates. The author, through studying New York's women's clothing industry, identified in competing businesses, linked by embedded ties, both competition as well as cooperation. Apart from competing with each other, their relations were characterized by trust, fine-grained information transfer and joint problem-solving arrangements. In the competing businesses linked by arm's-length (market) ties, only competition was identified, namely, the relationships between the companies was characterized by lack of reciprocity, non repeated interaction and an economic focus on transactions.

Within any relationship, cooperation and competition may coexist, which is called coopetition (Bengston and Kock, 1999; Dowling, Roering, Carlin, and Winieski, 1996; Gnyawali and Madhavan, 2001; Lado et al., 1997; M'Chirgui, 2005; Tsai, 2002), and they may lead the partner companies to a better performance (Gnyawaly and Madhavan, 2001). Interorganizational relationships constitute the coopetition' social structure, which manifests strategies both for cooperation as well as for competition (Chien and Peng, 2005). While Dowling, Roering, Carlin and Wisnieski (1996) indicated the probability of an increase in coopetitive relationships, Ketchen, Snow and Hoover (2004) state that, in reality, coopetition is increasing.

Although competitive and cooperative paradigms dominate the theory and the research about interorganizational relationships, few studies have emphasized the benefits that companies may obtain when they compete and cooperate simultaneously (M'Chirgui, 2005). This coopetitive behavior is apparent in industries based on knowledge, especially in the information technology domain (Carayannis and Alexander, 1999), in biotechnology (Quintana-Garcia and Benavides-Velasco, 2005), at total speed in smart card applications (M'Chirgui, 2005) and in the simulators industry (Chien and Peng, 2005). The coopetition was also identified among the chemical industry companies in Estonia (Seppo, 2007), as well as in the crystal (and glass) sector in Portugal (Lorga, 2002).

There are several perspectives that offer a useful theoretical table to analyze coopetition, such as RBV resource-based view and dynamic capabilities that can explain organizational performance through the use and development of internal and external resources (M'Chirgui, 2005). The necessary resources to reach organizational goals may belong to the company (internal resources) or not. If the company does not possess the resources, there is a possibility of acquiring them with other companies in the environment, through buying (market resources) or through interorganizational relationships (relational resources) (Sanchez, 1995). Therefore, the organizations depend upon others in terms of resources, and that dependency will result in organizational relationships (Aldrich and Pfeffer, 1976).

Organizations can be seen as opens systems that necessarily bargain (Pfeffer, 1992) or make exchanges (in the words of Levine and White, 1961) within the environment in order to acquire resources (Pfeffer, 1992), because they are not capable of internally generating all the necessary resources to maintain themselves (Aldrich and Pfeffer, 1976). To those authors, the interorganizational relationships are considered a special case study of the relations between the organizations and their environments.

The environment may be viewed as an inventory of resources which are rare, valuable and essential (Pfeffer, 1972a; 1972b) to the organizational survival (Pfeffer and Salancik, 1978).

\section{Methodology}

This is an ex post factum, sectional, descriptive-quantitative research. The level of analysis is organizational; the analysis unit is the organization. The population is made up of 47 exporting companies from the city of Maringá (PR). The questionnaires were made use in 31 exporting companies, $66 \%$ of the population. The collected data was analyzed through Univariate parametric statistics (ANOVA - GLM Univariate) and network analysis (centrality calculation)

\section{Analysis}

The analysis of the interorganizational social networks was stated by identifying the organizations (companies and cooperatives) with which each export company from Maringá keeps in contact more frequently. It was observed that most companies indicated three or four other

Revista de Negócios, v. 20, n. 3, p. 7-15, July, 2015. 
organizations with which they keep in contact more frequently. The average number of organizations with which each export company in Maringá keeps in touch more frequently is 3.6 organizations.

It was observed that the export companies did not mention other export companies from Maringá (PR) as organizations with which they keep in contact more frequently, with the exception of two, which mentioned each other: Recco (beachwear) e Recco (lingerie). This means that each company has an interorganizational social network, but these networks are isolated from one another. Because of the, it was deemed unnecessary to elaborate a sociogram depicting these isolated networks.

There is a need to clarify the relationship between Recco (lingerie) e a Recco (beachwear), which is characterized by frequent and embedded ties, in which each company plays more than one role in relation to the other. Recco (lingerie) is a client of Recco (beachwear), and the later in turn is a supplier of Recco (lingerie). Moreover, they are partners when dealing with the export business.

The city of Maringá export companies' interorganizational relationships are focused on the chain of value (buyers and suppliers) and tend to be type $1 \mathrm{~A}$. They are characterized by more social embeddedness (Uzzi, 1997) frequent interaction (Granovetter, 1985) and one role played (Ross and Robertson, 2007), since from the 108 mentioned companies, 100 present only one type of relationship with export companies.

Uzzi's work results (1997) suggest that in embedded ties relationships there are simultaneously cooperation and competition, that is, there is coopetition (Bengston and Kock, 1999; Dowling et al., 1996; Gnyawali and Madhavan, 2001; Lado et al., 1997; M'Chirgui, 2005; Tsai, 2002). Among the 108 organizations listed by export companies, four were competing organizations, so there is some evidence of coopetition.

Being part of trade associations is a way of relating to your competitors. Six export companies reported being part of trade associations. Another way of relating to your competitors is to constitute a new company to market the products, especially abroad, which was reported by two companies. It is noted that being part of trade associations and companies entails indirect relationships with the competitors consequently there is evidence of coopetition through being part of trade associations and other companies.

In view the specific goal of characterizing interorganizational social networks in the city of Maringa's export companies, the relational data, collected via a questionnaire, was inserted in a database of the Ucinet 6 program to configure an affiliation matrix (Wasserman and Faust, 1999), which referred to the relationships of the city of Maringa's export companies with regional institutions.

The previously identified regional institutions, which therefore were included in the questionnaire are as follows: (1) Mercosul Institute/ACIM; (2) Embassy/consulate; (3) CIN/FIEP; (4) CEF (Caixa Econômica Federal Brazil's Federal Central Bank); (5) Customs Clearance Broker; (6) SEBRAE; (7) SINDIMETAL; (8) AIESEC; (9) Banco do Brasil; (10) Trading; (11) Customs.

Affiliation networks are two-mode, but have only one set of agents (in this case the export companies). The second way in an affiliation network is a group of events (in this case the regional institutions) to which the agents belong to. The data in an affiliation network are the agents and the events, the events are defined not by pairs of agents, but by subgroups of agents, each agent subgroup is a collection of agents that participate in one specific event (Wasserman and Faust, 1999, p. 30).

Seeking to reach a clearer representation of the city of Maringa export companies' interorganizational relationships, the relational data matrix was analyzed and originated several socio-metrical maps sociogram.

The sociogram shown in figure 3 represents the links between the city of Maringa's export companies and regional institutions. As it can be observed, five institutions (Mercosul Institute, Customs Clearance Broker, Banco do Brasil, Trading e Customs) seem to be more central in relation to the other six that are located in more peripheral regions of the network (Embassy/consulate, CIN/FIEP, CEF, SEBRAE, SINDIMETAL e AIESEC).

Figura 3. Social network configuration between companies and institutions

Revista de Negócios, v. 20, n. 3, p. 7-15, July, 2015. 


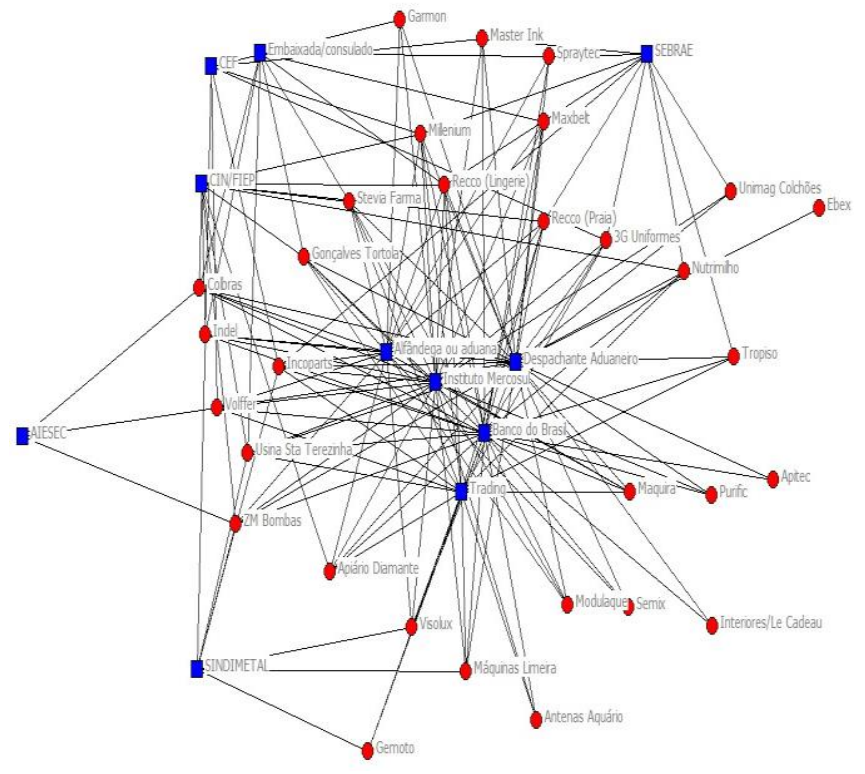

\begin{tabular}{|c|c|}
\hline Subtitle & \\
\hline$\square$ & Institutions \\
\hline$\bigcirc$ & Companies \\
\hline
\end{tabular}

Source: Research data

Considering that the institutions named as Embassy/consulate, Customs Clearance Broker and trading do not represent just one organization, the choice was made to exclude them from the analysis and to redo the sociogram, here shown in figure 4, which represents the links between the city of Maringa's export companies and the regional institutions. As it can be observed, three institutions (Mercosul Institute, Banco do Brasil e Customs Clearance Broker) are more central in relation to the other five that are located in more peripheral regions of the network (CIN/FIEP, CEF, SEBRAE, SINDIMETAL e AIESEC).
Figura 4. Social Network configuration between companies and institutions after excluding three institutions

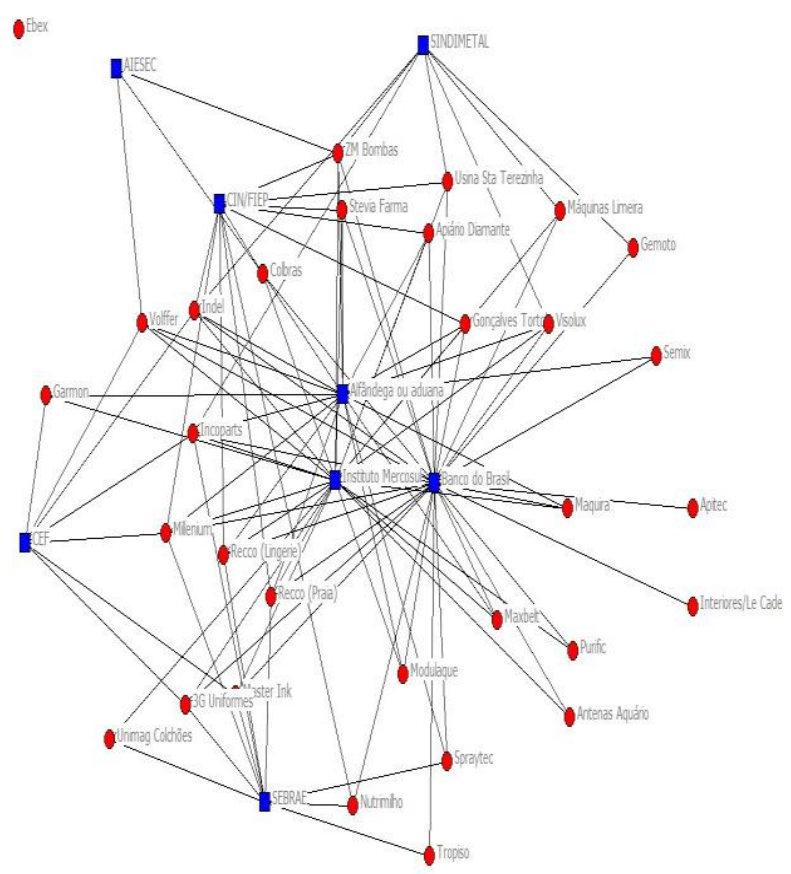

Source: Research data

\begin{tabular}{|c|l|}
\hline Subtitle & \\
\hline$\square$ & Institutions \\
\hline$\bigcirc$ & Companies \\
\hline
\end{tabular}

The sociogram shown in figure 5 represents the links between the city of Maringa's export companies by type of export and the regional institutions. As can be observed, the regular export companies tend to be more central than the sporadic export companies. Noting that Ebex, a sporadic export company, is left totally isolated, when the Customs Clearance Broker and two other institutions are taken out of the sociogram. 
Figure 5. Social network configuration between companies considering type of exports and institutions after the exclusion of three institutions

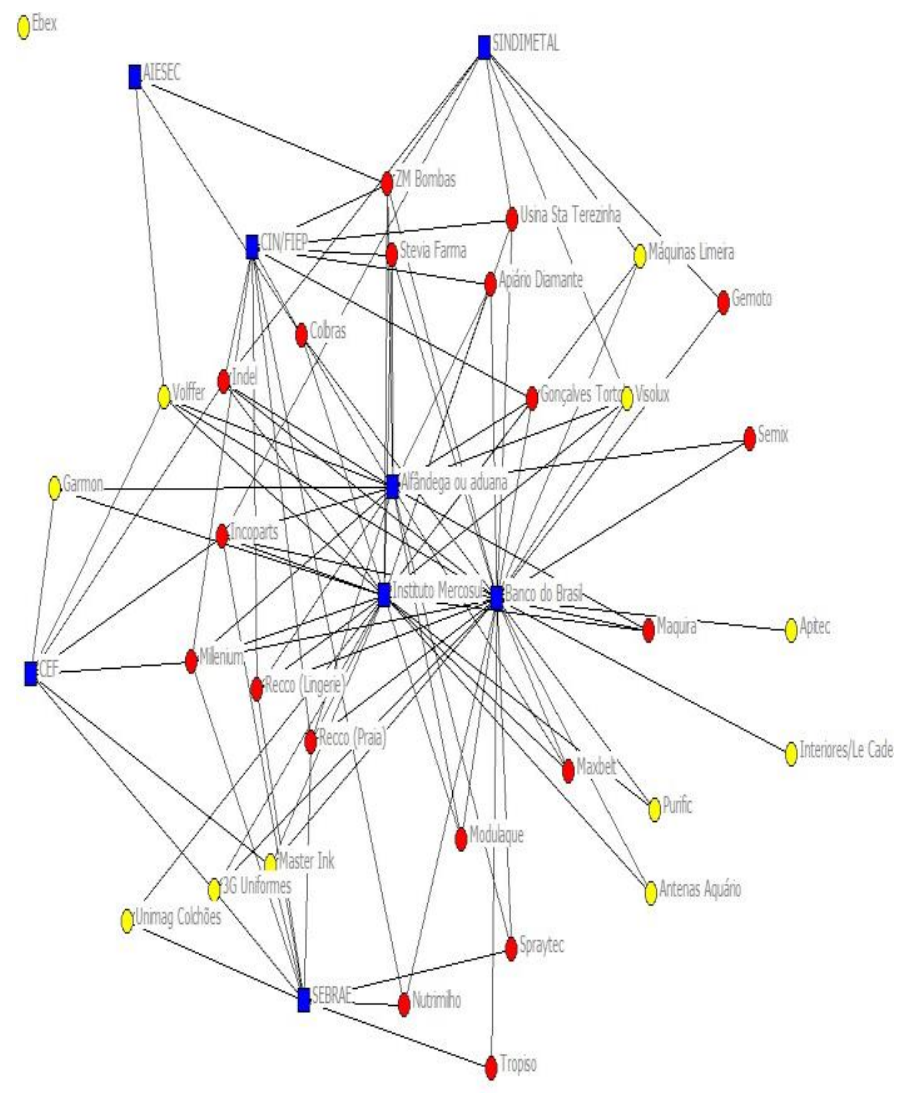

Source: Research data

\begin{tabular}{|c|l|}
\hline Subtitle & \\
\hline$\square$ & Institutions \\
\hline$\bigcirc$ & Regular exporters \\
\hline$\bigcirc$ & Sporadic exporters \\
\hline
\end{tabular}

\subsection{Centrality calculations}

One on the main purposes of the use of sociograms in network analysis is the identification of the network's most important agents and centrality measurement is one of the ways to quantify this importance (Wasserman and Faust, 1999). Aiming to quantify the importance of the city of Maringa's export companies as well as the regional institutions, several centrality calculations were carried out.
Table 1. Centrality degree of the exporting companies in the city of Maringá (PR)

\begin{tabular}{|c|c|c|c|}
\hline Companies & Degree 1 & $\begin{array}{l}\text { Degree } \\
2\end{array}$ & $\begin{array}{l}\text { Degree } \\
3\end{array}$ \\
\hline Indel & 8 & 88 & 94 \\
\hline Millenium & 8 & 91 & 97 \\
\hline Recco (Lingerie) & 8 & 85 & 90 \\
\hline Incoparts & 8 & 87 & 93 \\
\hline ZM Bombas & 7 & 84 & 90 \\
\hline Volffer & 7 & 74 & 79 \\
\hline Gonçalves e Tortola & 7 & 76 & 80 \\
\hline Usina Sta Terezinha & 7 & 65 & 69 \\
\hline Stevia Farma & 7 & 76 & 80 \\
\hline Colbras & 7 & 78 & 83 \\
\hline Recco (Praia) & 7 & 85 & 90 \\
\hline Apiário Diamante & 6 & 76 & 80 \\
\hline Visolux & 6 & 72 & 76 \\
\hline 3G Uniformes & 6 & 64 & 68 \\
\hline Máquinas Limeira & 5 & 55 & 58 \\
\hline Maxbelt & 5 & 66 & 69 \\
\hline Master Ink & 5 & 64 & 68 \\
\hline Nutrimilho & 5 & 46 & 49 \\
\hline Spraytec & 5 & 53 & 56 \\
\hline Maquira & 5 & 66 & 69 \\
\hline Modulaque & 4 & 66 & 69 \\
\hline Tropiso & 4 & 33 & 38 \\
\hline Garmon & 4 & 45 & 48 \\
\hline Semix & 3 & 44 & 46 \\
\hline Antenas Aquário & 3 & 49 & 51 \\
\hline Gemoto & 3 & 33 & 35 \\
\hline Purific & 3 & 49 & 51 \\
\hline Unimag Colchões & 3 & 31 & 33 \\
\hline Interiores/Le Cadeau & 2 & 27 & 28 \\
\hline Apitec & 2 & 27 & 28 \\
\hline Ebex & 1 & 0 & 0 \\
\hline
\end{tabular}

Fonte: Research data

Initially, the degree of centrality that each of Maringa's exporting company has, was calculated, and consequently the number of contacts that each company has with regional institutions. The four companies which presented the highest degree of centrality were: Indel, Millenium, Recco (Lingerie) and Incoparts, each with eight contacts. Ebex presented the lowest centrality level with just one contact with Customs Clearance Broker (see table 1 - degree 1)

Aiming to confirm the apparent centrality of some institutions, revealed by the sociogram shown in figure 3 , two centrality calculations were conducted: first, the degree of centrality of regional institutions was calculated, taking into

Revista de Negócios, v. 20, n. 3, p. 7-15, July, 2015. 
consideration with how many of the city of Maringa's export companies they relate to. This calculation confirms the sociogram's apparent centrality of the following institutions: Customs Clearance Broker, Banco do Brasil, Mercosul Institute, Customs (see table 2-degree 1).

Tabela 2. Regional institutions centrality degree

\begin{tabular}{l|l|l}
\hline Regional institutions & Degree 1 & Degree 2 \\
\hline Customs Clearance Broker & 29 & 117 \\
Banco do Brasil & 28 & 121 \\
Mercosul Institute & 23 & 063 \\
Customs & 18 & 054 \\
Trading & 17 & 045 \\
CIN/FIEP & 11 & 029 \\
SEBRAE & 10 & 018 \\
Embassy/consulate & 08 & 017 \\
CEF & 07 & 025 \\
SINDIMETAL & 07 & 018 \\
AIESEC & 03 & 010 \\
\hline
\end{tabular}

Fonte: research data

Secondly, regional institutions centrality degree was calculated, taking into account the frequency of contact of the city of Maringa's export companies with these regional institutions, namely, the importance was weighed by the contact frequency. This calculation confirms the apparent centrality in the sociogram of the following institutions: Customs Clearance Broker, Banco do Brasil, Mercosul Institute, Customs and trading (see table 2- degree 2)

The two performed calculations, aiming to confirm the apparent centrality of some regional institutions, revealed by the sociogram represented by figure 3 , that are, (1) the centrality degree of regional institutions, taking into account to how many of the city of Maringa's export companies they relate to (table 2 - degree 1 ), and (2) the centrality degree of regional institutions, taking into account the contact frequency of the city of Maringa's export companies with these regional institutions (table 2 - degree 2), do confirm the apparent centrality in the sociogram of the following institutions: Customs Clearance Broker, Banco do Brasil, Mercosul Institute, Customs and trading. There is an inversion in the centrality degree order from the first to the second calculation. Customs Clearance Broker, goes from first to second place and Banco do Brasil from second to first place. Considering the mentioned institutions such as embassy/consulate, Customs Clearance Broker, and trading did not represent just one organization, the choice of excluding them and to redo the centrality degree calculations of the city of Maringa's export companies was made.

First, the centrality degree of each of Maringá's export companies was calculated, that is, what is the number of contacts that each company has with other companies, through regional institutions. The six companies that presented the highest centrality degree were Millenium, Indel, Incoparts, Recco (beachwear), Recco (Lingerie) e ZM Bombas. Ebex presented a zero centrality degree since its only contact, Customs Clearance Broker, was eliminated from the calculations (see table 1 - degree 2).

Secondly, the centrality degree of each of Maringa's export company was calculated, considering the number of regional institutions, that is to say, apart from the number of contacts that each company has with other companies through regional institutions, the number of contacts the companies have with regional institutions was added. The six companies that presented a highest centrality degree were Millenium, Indel, Incoparts, ZM Bombas, Recco (beachwear) e Recco (Lingerie). Ebex presented a zero centrality degree since its only contact, Customs Clearance Broker, was eliminated from the calculations (see table 1 - degree 3 ).

When comparing the three performed centrality degree calculations of the city of Maringa's export companies (see table 1 - degrees 1,2 and 3), it is observed that: (1) the eleven companies with the highest centrality degree vary very little. when the centrality calculation is done considering all the regional institutions, Usina Santa Terezinha is part of the top eleven companies (table 1 - degree1); when the centrality calculation is done considering only eight regional institutions, Usina Santa Terezinha is not part of the top eleven and yields its place to Apiário Diamante (table 1 - degrees 2 and 3 ). That is a consequence of Usina relating to three of the institutions that were taken off to do the calculation (embassy/consulate, Customs Clearance Broker, and trading); (2) when the centrality calculation is done considering only eight regional institutions (table 1 - degrees 2 and 3 ), the eleven companies with the highest centrality degree are exactly the same. The only difference appears when the calculation considers the number of regional institutions (table 1 -

Revista de Negócios, v. 20, n. 3, p. 7-15, July, 2015. 
degree 3) ZM Bombas stays ahead of Recco (Beachwear) and Recco (Lingerie)

As a result of the centrality analysis of the city of Maringa's export companies, the following hypothesis was developed.

H1: There is a positive relationship between centrality and regular exporting.

That is, the companies that export more regularly are more central than the ones that export sporadically. Centrality reflects the importance of the company, and, as a rule, this importance is linked to the size. To control the possible effect of size in centrality, the size was added to the model as a control variable. To allow the use of size by SEBRAE's criteria (2004), micro and small companies were grouped in one category and medium and big in another, thus eliminating the zeros.

To test the hypothesis, a General Linear Model technique was used, found in the statistical package SPSS 13.0. This technique allows the testing of the hypothesis that the average of a dependent variable are different between groups (independent variable). Furthermore, different from the ANOVA One-Way, it is possible to add to the model independent control variables, such as categorical and continuing, which allows a better refinement of the analysis, since the variation of the dependent variable, that is shared by the control variables, is removed before the variation is attributed to the independent variable which is being tested (Cramer, 2006). The model tested is presented below.

Centrality $=\mathrm{B}_{0}+\mathrm{B}_{1}$ Type of export $+\mathrm{B}_{2}$ SEBRAE Size

Considering that centrality is the dependent variable, $\mathrm{B}_{0}$ is the intercept, Type of export is the independent variable to be tested in the hypothesis and the variable SEBRAE size is used as the control variable. Initially, to test the model, the Levene equal variance test was done between the groups. Since the test was not significant at $90 \%$, the hypothesis of equal variance between the groups was corroborated, which allows for the model GLM test.

It should be made clear that the hypothesis was tested twice, each time using a different degree of centrality: first, the centrality degree of each of Maringa's export company has was used, that is, the number of contacts that each company has with other companies through regional institutions (table 1 - degree 2). Then, the centrality degree that each export company from Maringá has was used, this time considering the number of regional institutions, that is, apart from the number of contacts that each company has with other through regional institutions, the number of contacts the companies have with the regional institutions was added (table 1 - degree 3 ). The results of both hypothesis tests show that regular exporting is linked positively to centrality, when controlled by size, with a significance rate of $95 \%$. For lack of space, the results could not be presented in their entirety.

\section{Conclusion}

When considering the relationships with organizations (companies and cooperatives), export companies concentrate their relationships in the value chain, which includes buyers and suppliers. These relationships tend to be embedded and frequent, within which each company plays only one role in relation to the other.

When considering relationships with regional institutions, export companies tend to relate more to five institutions: Mercosul Institute, Customs Clearance Broker, Banco do Brasil, trading e Customs. By eliminating the institutions embassy/consulate, Customs Clearance Broker and trading, since they do not represent one single institution, the institutions that stand out are Mercosul Institute, Banco do Brasil and Customs.

The importance of the Mercosul Institute to the city of Maringa's export companies was confirmed as this research developed. It is the only institutions focused on exporting based in this city. Among the 31export companies studied, 23 stated having a relationship with the Institute. The centrality calculations (see table 2 - degree 1 , 2 and 3) confirm the apparent importance of the Mercosul Institute revealed through the sociograms.

Participation in institutions such as the Institute Mercosur increases the possibility of acquiring competitive capabilities, or new information and opportunities with respect to internationalization. Regional institutions are essential for the discovery of new foreign markets.

Revista de Negócios, v. 20, n. 3, p. 7-15, July, 2015. 
A subject deserves to be highlighted: coopetition, namely, the existence of cooperation and competition between competing companies. Even though only four export companies mentioned their competitors as organizations with which they keep more frequent contact, there is evidence of the existence of coopetition in these relationships. Eight companies mentioned trading associations and companies made up of competitors as institutions with which they keep more frequent contact, that is, these companies keep in touch with competitors through institutions, and therefore, there is evidence of the existence of coopetition in these relationships.

The main theoretical contributions result from the relationship between the process of internationalization and networks of interorganizational relationships. Regular exporters are more central than sporadic exporters. This means that regular exporters maintains more than interorganizational relationships than sporadic exporters, that is, greater number of relationships maintained greater involvement in the foreign trade. This reinforces the assumption of economic sociology that economic actions are embedded in social networks, that is, reinforces social embeddedness. Exporting companies in general, maintains relationships with other organizations characterized by embedded, strong and simple ties. Exporting companies also maintains relationships with regional institutions, which are considered a substitute of weak ties. Relationships maintained with organizations and regional institutions reinforce the assumption of social networking theory that different types of ties are required for companies to achieve competitive advantage because each type of tie offers different opportunities. This work also reinforces that one of benefits of coopetition is to improve the competitive position of companies with respect to internationalization.

\section{Implications and Further Research}

Some limitations must be discussed. First, the number of companies (31) in the sample. It limits the statistical analysis. In trying to mitigate this problem, all the questionnaires were applied in loco assuring that the respondents were the correct informants. Besides that, the number of variables in the ANOVA - GLM was limited to two, trying to keep the statistical power.
As future research suggestion, the populations should be expanded. The role of institutions should be analyzed in depth, especially of the Mercosul Institute and the Banco do Brasil. Finally, the role of institution in the coopetition should be analyzed. Is it possible coopetition intermediated by an institution?

\section{References}

Aldrich, H.E. (1979). Organizations and environments. Englewood Cliffs: Prentice Hall.

Aldrich, H.E., \& Pfeffer, J. (1976). Environment of organizations. Annual Review of Sociology, 2, 79-105.

Barnard, C.I. (1979). As funções do executivo. São Paulo: Atlas.

Barney, J. (1991). Firm resources and sustained competitive advantage. Journal of Management, 17(1), 99-120.

Bengtsson, M., \& Kock, S. (1999) Cooperation and competition in relationships between competitors in business networks. Journal of Business \& Industrial Marketing, 14(13), 178-193.

Boehe, D.M., \& Toni, D.D. (2006) Modelo para internacionalização de empresas baseada em redes. Anais do Simpósio de Gestão e Inovação Tecnológica, Gramado, RS, Brasil, 24.

Bulgacov, S., \& Verdu, F.C. (2001) Redes de pesquisadores da área de administração: um estudo exploratório. Revista de Administração Contemporânea, 5(edição especial), 163-182.

Burt, R.S. (1992). Structural holes: the structure of competition. Harvard University Press: Cambridge (MA).

Carayannis, E.G., \& Alexander, J. (1999). Winning by co-opeting in strategic Governmentuniversity-industry R\&D partnerships: the power of complex, dynamic knowledge networks. Journal of Technology Transfer, 24, 197-210.

Castells, M. (1999) A sociedade em rede -a era da informação: economia, sociedade $e$ cultura. Porto Alegre: Paz e Terra.

Che Senik, Z., Scott-Ladd, B., Entrekin, L., \& Adham, K.A. (2011). Networking and internationalization of SMEs in emerging economies. Journal of International Entrepreneurship, 9, 259-281.

Chen, H., \& Chen, T. (1998). Network linkages and location choice in foreign direct investment. Journal of International Business

Revista de Negócios, v. 20, n. 3, p. 7-15, July, 2015. 
Studies, 29(3), 445-468.

Chetty, S., \& Agndal, H. (2007). Social capital and its influence on changes in internationalization mode among small and medium-sized enterprises. Journal of International Marketing, 15(1), 1-29.

Chetty, S., \& Campbell-Hunt, C. (2004). A strategic approach to internalization: a traditional versus a "born global" approach. Journal of International Marketing, 12(1), 57-81.

Chien, T., \& Peng, T. (2005). Competition and cooperation intensity in a network: a case study in Taiwan simulator industry. Journal of American Academy of Business, 7 (2), 150-155.

Child, J., \& Rodrigues, S.B. (2006). The process of SME internationalization: British firms entering in Brazil. Anais do EnANPAD, Salvador, Bahia, Brasil, 30.

Cramer, D. (2006). Advanced Quantitative Data Analysis. Maidenhead - PA: Open University Press.

Dib, L.A., Rocha, A., \& Silva, J.F. (2010). The internationalizations process of Brazilian software firms and the born global phenomenon: examining firm, network, and entrepreneur variables. Journal of International Entrepreneurship, 8, 233-253.

Dowling, M.J., Roering, W.D., Carlin, B.A., \& Wisnieski, J. (1996). Multifaceted relationships under coopetition. Journal of Management Inquiry, 5(2), 155-167.

Freeman, S., Edwards, R., \& Schroder, B. (2006). How smaller born-global firms use networks and alliances to overcome constraints to rapid internationalization. Journal of International Marketing, 14(3), 33-63.

Gnyawali, D.R., \& Madahvan, R. (2001). Cooperative networks and competitive dynamics: a structural embeddedness perspective. Academy of Management Review, 26(3), 431-445.

Granovetter, M. (1973). The Strength of Weak Ties. American Journal of Sociology, 78(6), 1360-1380.

Granovetter, M. (1974). Getting a job: a study of contacts and careers. Cambridge, Massachusetts: Harvard University Press.

Granovetter, M. (1983). The Strength of Weak Ties: a network theory revisited. Sociological Theory, 1, 201-233.

Granovetter, M. (1985). Economic action and social structure: the problem of embeddedness. American Journal of Sociology,
91(3), 481-510.

Hamel, G., \& Prahalad, C.K. (1990). The core competence of the corporation. Harvard Business Review, 79-91.

Hamel, G., \& Prahalad, C.K. (1995) Competindo pelo futuro. Rio de Janeiro: Campus.

Hamel, G., \& Prahalad, C.K. (1998). A competência essencial da corporação. In Montogomery, C.A., \& Porter, M.E. (orgs). Estratégia: a busca da vantagem competitiva. Rio de Janeiro: Campus.

Johanson, J., \& Vahlne, J. (1977). The internationalization process of the firm. Journal of International Business Studies, 8, 23-32.

Johanson, J., \& Vahlne, J. (2003) Business relationship learning and commitment in the internationalization process. Journal of International Entrepreneurship, 1(1), 83-101.

Ketchen, D.J., Jr., Snow, C.C., \& Hoover, V.L. (2004). Research on competitive dynamics: recent accomplishments and future challenges. Journal of Management, 30(6), 779-804.

Lado, A.A., Boyd, N.G., \& Hanlon, S.C. (1997). Competition, cooperation, and the search for economic rents: a syncretic model. Academy of Management Review, 22(1), 110-141.

Levine, S., \& White, P.E. (1961). Exchange as a conceptual framework for the study of interorganizational relationships. Administrative Science Quarterly, 5, 583-601.

Loane, S., \& Bell, J. (2006). Rapid internationalisation among entrepreneurial firms in Australia, Canada, Ireland and New Zealand: an extension to the network approach. International Marketing Review, 23 (5), 467-485.

Lorga, S. (2002). A internacionalização e os mecanismos de cooperação em rede na Vitrocristal, ACE. (Working Paper). Faculdade de Economia e Gestão, Universidade Católica Portuguesa.

M'Chirgui, Z. (2005). The economics of the smart card industry: towards coopetitive strategies. Economics of Innovation \& New Technology, 14(6), 445-477.

Maciel, C.O. (2007). Práxis estratégica e imersão social em uma rede de organizações religiosas. Dissertação (Mestrado em Administração)-Setor de Ciências Sociais Aplicadas, Universidade Federal do Paraná, Curitiba.

Martes, A.C.B., Bulgacov, S., Reinert, M.R., Gonçalves, S.A., \& Augusto; P.O. (2006).

Revista de Negócios, v. 20, n. 3, p. 7-15, July, 2015. 
Fórum - redes sociais e interorganizacionais. Revista de Administração de Empresas, 46(3), 1015.

Mort, G.S., \& Weerawardena, J. (2006). Networking capability and international entrepreneurship: how networks function in Australians born global firms. International Marketing Review, 23 (5), 549-572.

Nash, J.F., Jr. (1950).The bargaining problem. Econometrica, 18(2), 155-162.

Nash, J.F., Jr. (1953). Two person cooperative games. Econometrica, 21(1), 128140.

Oliver, C. (1990). Determinants of interorganizational relationships: integration and future decisions. Academy of Management Review, 15(2), 241-265.

Pfeffer, J. (1972a). Size and composition of corporate boards of directors: the organization and its environment. Administrative Science Quarterly, 17(2), 218-228.

Pfeffer, J. (1972b). Merger as a response to organizational interdependence. Administrative Science Quarterly, 17(3), 382-394.

Pfeffer, J. (1992). A resource dependence perspective on intercorporate relations. In Mizruchi, M., \& Schwartz, M. (1992). Intercorporate relations. Cambridge University Press.

Pfeffer, J., \& Salancik, G.R. (1978). The external control of organizations: a resource dependence perspective. New York: Harper \& Row.

Porter, M.E. (1986). Estratégia competitiva: técnicas para análise de indústrias e da concorrência. 7. ed. Rio de Janeiro: Campus.

Powell, W.W., \& Smith-Doerr, L. (1994). Networks and economic life. In Smelser, N.J., \& Swedberg, R. The handbook of economic sociology. Princeton: Princeton University Press.

Quintana-Garcia, C., \& Benavides-Velasco, C.A. (2005). Agglomeration economies and vertical alliances: the route to product innovation in biotechnology firms. International Journal of Production Research, 43(22), 4853-4873.

Reinert, M. (2006). O processo de negociação empresa-governo na atração de IDE e os relacionamentos com as organizações locais. Tese (Doutorado em Administração)-Escola de Administração de Empresas da Fundação Getúlio Vargas, São Paulo.

Reinert, M. (2008a). A formação de relacionamentos com as organizações locais: a influência do processo de negociação empresagoverno na atração de Investimento Direto Estrangeiro (IDE). Anais do Workshop Empresa, Empresário e Sociedade, Niterói, Rio de Janeiro, Brasil, 6.

Reinert, M. (2008b). A influência do contexto na formação dos relacionamentos com organizações locais: estudo comparativo de casos em empresas automotivas. Anais do Encontro de Administração Pública e Governança, Salvador. Bahia, Brasil, 3.

Rezende, S.F.L., \& Versiani, A.F. (2007). Relacionamentos intersubsidiárias e processos de internacionalização de multinacionais. Revista de Administração, 42(2), 155-166.

Ross, W.T., Jr., \& Robertson, D.C. (2007). Compound relationships between firms. Journal of Marketing, 71, 108-123.

Rubinstein, A. (1995). John Nash: the master of economic modeling. Scandinavian Journal of Economics, 97(1), 9-13.

Sanchez, R. (1995). Strategic flexibility in product competition. Strategic Management Journal, 16(special issue), 135-159.

Scott, J. (2003). Social network analysis. 2 ed. London: Sage Publications.

Seppo, M. (2007). The role of business network in the internalization of Estonian chemical industry enterprises. Tartu University Press, 1-44.

Smelser, N.J., \& Swedberg, R. (2005) Introducing economic sociology. In Smelser, N.J., \& Swedberg, R. The handbook of economic sociology. 2. ed. Princeton: Princeton University Press.

Swedberg, R., \& Granovetter, M. (2001). Introduction to the second edition. In Granovetter, M., \& Swedberg, R. The sociology of economic life. 2. ed. Boulder, CO: Westview Press.

Teece, D.J., Pisano, G., \& Shuen, A. (1997). Dynamic capabilities and strategic management. Strategic Management Journal, 18(7), 509-533.

Tsai, W. (2002). Social structure of coopetition within a multiunit organization: coordination, competition, and intraorganizational knowledge sharing. Organization Science, 13(2), 179-190.

Uzzi, B. Social structure and competition in interfirm networks: the paradox of embeddedness. Administrative Science Quarterly, 42, 35-67.

Wasserman, S., \& Faust, K. (1999). Social

Revista de Negócios, v. 20, n. 3, p. 7-15, July, 2015. 
network analysis: methods and applications.

Cambridge: Cambridge University Press.

Wernerfelt, B. (1984). A resource-based view of the firm. Strategic Management Journal, 5(2), 171-180.

Revista de Negócios, v. 20, n. 3, p. 7-15, July, 2015. 